Article title: Supporting ABET Students at Unisa during the Fourth Industrial Revolution

Authors: Gezani Baloyi[1]

Affiliations: Adult Basic Education and Training, University of South Africa[1]

Orcid ids: 0000-0002-3581-5539[1]

Contact e-mail: baloygp@unisa.ac.za

License information: This work has been published open access under Creative Commons Attribution License $\mathrm{http}: / / c r e a t i v e c o m m o n s . o r g / l i c e n s e s / b y / 4.0 /$, which permits unrestricted use, distribution, and reproduction in any medium, provided the original work is properly cited. Conditions, terms of use and publishing policy can be found at https://www.scienceopen.com/.

Preprint statement: This article is a preprint and has not been peer-reviewed, under consideration and submitted to UnisaRxiv for open peer review.

Funder: N/A

DOI: $10.25159 /$ UnisaRxiv/000025.v1

Preprint first posted online: 29 July 2021

Keywords: adult learner, open distance and e-learning, student support, Fourth Industrial Revolution, adult basic education and training, open distance learning 


\title{
Supporting ABET Students at Unisa during the Fourth Industrial Revolution
}

\author{
Gezani Baloyi \\ https://orcid.org/0000-0002-3581-5539 \\ University of South Africa \\ baloygp@unisa.ac.za
}

\section{Abstract}

Teaching adult students in the context of the Fourth Industrial Revolution poses numerous difficulties in the global higher education context. Unisa students are generally adults who are working, but younger students also register with the institution, and they require support. The paper focuses on the adult students in the ABET department, which falls within the School of Educational Studies. The ABET student cohort comprises both older and younger students who are keen to learn. However, the lack of internet connectivity makes teaching and supporting them during the Covid-19 pandemic difficult, with a number of students situated in the rural areas. For the study, the researcher used the community of inquiry theoretical framework, which promotes interaction between student, teacher and content. At Unisa, teaching and learning take place on the myUnisa learning management system. The findings suggest that some students do not have the necessary skills to use myUnisa. The lack of skills in the use of technologies is a cause for concern.

Keywords: adult learner, open distance and e-learning, student support, Fourth Industrial Revolution, adult basic education and training, open distance learning

\section{Introduction}

The notion of the Fourth Industrial Revolution (4IR) was put forward by Klaus Schwab, founder of the World Economic Forum, to capture the rapidity and scale of technological change and its impact on society (Mdluli and Makhupe 2017 , 4). The changes driven by technological transformation influence the way we do things daily. The World Economic Forum $(2015,5)$ has identified six software and services megatrends which are shaping society, namely, people and internet, computing, ubiquitous communications and storage, the internet of things (IoT), artificial intelligence (AI), and big data today and which are dependent on intelligent technology that is powered by AI (Xing and Marwala 2017).

The University of South Africa (Unisa) began as a correspondence university, serving students who were working full time. Currently, Unisa has adopted open distance and 
e-learning as its business model, enabling the university to register many students who previously did not have access to higher education in South Africa, in the southern African region and in other countries of the world. Unisa therefore had to introduce support systems and structures to support the students from a range of backgrounds; in consequence, the support mechanisms have to be diversified, as the institution has undertaken to place students first on its teaching and learning agenda. According to Thorpe (2002), Simpson (2002) and Tait (2003), supporting students contributes to promoting the student success rate in distance education. Students studying via distance education experience very specific problems relating to this mode of teaching and learning. Many of the students who register with Unisa do so because the courses are less expensive than those offered by contact universities. Unisa thus recognised the need for student support in teaching and learning that take place on a learning management system.

In preparation for the full adoption of the open distance and e-learning model, the Unisa undergraduate modules have been placed on the university's online learning management system, myUnisa, as a means to facilitate access, and it is in this context that the Integrated Tutor Model (ITM) was introduced and formalised in 2013. Currently, Unisa students write their examinations online; this was made possible by integrating open distance and e-learning.

\section{Literature Review}

Globally, the concept of 4IR has changed the way institutions of higher learning have come to conduct teaching, learning, research, community engagement and academic citizenship. Schwab (2016a, 7) refers to these changes as the "fusion of technologies across the physical, digital and biological worlds". Universities play a vital role in shaping societies in the global context, in that they equip students with the skill set required to engage in economic activities.

The majority of graduates during the Third Industrial Revolution lacked the necessary skills to function fully in the economy of their country. Students therefore require extensive skills to function optimally in the 4IR.

The myUnisa learning management system includes e-tutoring, with the goal of improving the student success rate. According to Tait (2003), an effective student support system is at the heart of any open distance learning (ODL) institution. ODL institutions have developed and introduced systems and structures as part of their student support programmes. Segoe $(2017,161)$ reports an improvement in the learner success rate following the adoption by Unisa of a tutor support model. Mtsweni and Abdulla (2014) explain that tutors also perform a technical role in the facilitation of learning, since students need technical skills. This role is mostly performed when tutors facilitate online. 
Student support in distance education remains key to student success. Students in distance education study on their own without in-person supervision by their lecturers, and the fact that many drop out owing to a lack of student support is cause for concern. Most adult students display a high degree of motivation, and they bring a degree of experience to their learning. However, even though we are in the 4IR, many students lack internet connectivity in their environment.

The Unisa student population comprises both working adults and unemployed younger students, all of whom require support. Even though the students are motivated to learn, the lack of access to computer facilities for teaching and learning is a cause for concern. The research reported on in this paper sought to explore student support strategies as a means to lower the dropout rate in the adult basic education and training (ABET) department.

Human beings have undergone revolutions throughout the ages, and these revolutions have presented both opportunities and threats. In the 4IR, students should be equipped with a variety of technological skills to enable them to succeed in their studies, and so the Unisa programmes need to respond to the labour market of the twenty-first century. Even though the 4IR presents higher education institutions with challenges, for example, internet access, it promises more opportunities in teaching and learning. Machines are increasingly replacing human beings in the workplace, and institutions of higher learning should adopt new technologies to respond to the situation (Moche 2020).

Teaching and learning using technologies take place at a much faster pace, and technologies evolve rapidly (Agrawal, Gans, and Goldfarb 2018; Harari 2018; Marwala and Hurwitz 2017). Technology and machines are going to replace academics in the classrooms. This revolution influences the form taken by teaching and learning in institutions of higher learning. Students at Unisa learn and are supported on the myUnisa learning management system, which allows student-tostudent, student-to-content and student-to-teacher interactions to take place, thus promoting flexible teaching and learning and deep learning, all of which signal a fundamental shift in the way in which teaching and learning take place.

Because the technologies of the 4IR diffuse much faster, both students and lecturers need to be reskilled much faster. Unfortunately, the majority of Unisa students are still stuck in the Third Industrial Revolution, as they lack the necessary internet connectivity to access teaching and learning.

The technological advancement of the 4IR will on the one hand reduce the number of workers required to perform certain tasks, and on the other hand create increased demand for the performance of others, leading to new job creation (The Future of Jobs Report 2018, 10). The skills that will therefore be in demand are analytical thinking, innovation, active learning, creativity, technological design, complex problem-solving, 
leadership and social influence, reasoning, and systems analysis and evaluation (The Future of Jobs Report 2018, 12). Institutions of higher learning have a huge role to play in reskilling their students and graduates. However, the emphasis on some of these competencies is having a negative effect on adult students, at Unisa and elsewhere. Both the department and the university have expressed concern regarding students' lack of the digital competencies necessary to navigate the myUnisa learning management system. Generally, adult students find working with technology difficult, which has a negative effect on teaching and learning. Digital phobia, to use the informal term used to convey reluctance to become fully immersed in the digital age out of fear of negative consequences, may lead to a high dropout rate in both the ABET department and the university more widely.

Schwab (2016a) proposes four types of intelligence, namely, contextual, emotional, inspired, and physical intelligence, which are crucial to minimise the potential disruption brought about by the 4IR. Lorenz et al. $(2015,5)$, speaking of the rise of new digital industrial technologies, state that transformation will take place at a speed hitherto never experienced. Although it is not known at precisely what speed the 4IR will unfold, it is crucial that the response to it come from collective stakeholders, that is, the public and private sectors, academia and civil society (Schwab 2016a). In this wave of 4IR, the future presents numerous challenges and possibilities to stakeholders. A more optimistic view by Stewart, De and Cole $(2015,1)$ highlights the way in which technology has led to overall job creation in the past. In this age of machine intelligence, creative abilities, leadership skills and strategic thinking are important competencies (McAfee et al. 2014).

According to Makhanya (as cited in Ravhudzulo 2019, 1), the 4IR has changed the way in which institutions and markets operate in the twenty-first century. Institutions of higher learning have a role to play in educating society about the challenges and opportunities introduced by the 4IR. Institutions of higher learning as problem-solvers in society, and in teaching and supporting students using new technologies, become crucial.

This means that there should be a new pedagogy of student support using new technologies. In this paper I place student support in the centre of new technology pedagogy, even though most communities are still grappling with the digital divide. Castells $(2001,247)$ defines the digital divide as "inequality of access to the internet," Van Dijk $(2006,222)$ calls it the "gap between those who do and those who do not have access to the internet", and Norries $(2001,4)$ terms it "any and every disparity within the online community".

Within the context of the 4IR, when students need certain skills to participate in the labour market, institutions of higher learning have a role to play in transforming their curriculum to respond to labour market needs (Schwab 2016b). According to Brynjolfsson and McAfee (2014,9-11), because information and communication 
technologies diffuse much faster in the 4IR, graduates will need skills to respond to the labour market. Moloi and Marwala (2020) suggest that new technologies and computers that were dominant during the Third Industrial Revolution are currently needed to equip graduates with new skills that will assist the economy. AI, robotics, and the IoT have changed the labour market for the better during the 4IR.

The current president of South Africa, Mr Cyril Ramaphosa (2018), has encouraged institutions of higher learning and the private sector to start thinking about the adoption of 4IR. He conveyed this message after attending the World Economic Forum, where 4IR was discussed in detail (Schwab 2016b). The government has therefore mandated institutions of higher learning to overcome the difficulties and identify opportunities presented by 4IR.

Philbeck and Davis $(2018,18)$ remind us that the 4IR continues where the First, Second and Third Industrial Revolutions have left off, and that the information and communication technology of the Third Industrial Revolution is crucial and serves as the point of departure for the 4IR - the latter therefore does not occur in isolation from its predecessors.

\section{Research Problem}

The main problem identified in the research project was the challenges relating to student support for adult students in the context of the 4IR. Unisa has adopted an open distance and e-learning model to increase access to higher education. However, internet connectivity remains a problem to many students living in rural areas. Even though we find ourselves in the 4IR, both students and lecturers are not sufficiently reskilled to ensure student support on the myUnisa learning management system.

\section{Approach Used to Obtain Data}

For the purposes of this conceptual paper, the researcher reviewed literature on 4IR, open distance learning and new technologies, and adopted the community of inquiry approach to analyse the literature. Gilson and Golberg (2015) state that researchers use conceptual papers to interact with the literature while focusing on a particular research study.

\section{Discussion and Concluding Remarks}

According to the Future of Jobs Report (2018), graduates require skills to solve complex problems in society. There are a vast number of skills or competencies that students will require, such as social skills, which could include persuasion, emotional intelligence and teaching others, and cognitive skills, which could include creativity, mathematical reasoning, processing skills, and critical thinking. 
The Future of Jobs Report (2018, vii) identified four specific technological advances, namely, ubiquitous high-speed mobile internet, AI, the widespread adoption of big data analytics, and cloud technology as set to dominate between 2018 and 2022. These can be seen as the drivers of change.

Unisa has increasingly been required to anticipate the skills with which it will need to equip its students and graduates during the 4IR. The institution will have to work with companies to broaden the skills set of its students and graduates. The offerings that higher institutions make available should be in line with what the market requires.

Currently, the 4IR has made a rapid technological impact on higher education. Institutions of higher learning were aware of the advent of the 4IR, and so a necessary point of discussion is the preparedness of these institutions to embark on this journey. This revolution will be with us for many years to come, and its effects on higher education will not be fleeting. The literature review also indicated that society and institutions of higher learning are finding it difficult to adapt to the 4IR in the context of teaching and learning.

The 4IR brings exciting opportunities to society, institutions, the economy and industry. All of these are supportive of an environment that is conducive to teaching and learning. Institutions of higher learning should therefore embrace this revolution and make the best use of it. Moreover, the 4IR has arrived at a time when transformation is rapidly setting the tone in institutions of higher learning in South Africa, and will therefore proceed in tandem with the new ways of teaching and learning that transformation demands.

Marwala (2009) identifies three types of AI, namely, machine learning, computational intelligence, and soft computing. Machines replace human beings in teaching and learning in areas such as robotics. In group discussions on the learning management system, students interact with one another, and identify and solve learning problems. Marwala terms this individual intelligence, but collectively students can come up with a learning solution. This example shows the way in which AI influences teaching on learning management systems in open distance and e-learning. Students are able to upload assignments, post comments and watch videos as part of group discussion learning on a learning management system. This can be referred to as deep learning in the machine learning context. As Moloi and Marwala (2020,5) observe, the 4IR has changed the way people think and act in teaching, learning and the workplace.

According to the Future of Jobs (2016), the teaching and learning programmes that students take in higher education sometimes become redundant after four years because of technology diffusion in the economy and labour market. The curriculum that institutions offer need to be valid and to fulfil the societal needs of the twenty-first century. The students should be trained and supported with the relevant skills set. According to the National Development Plan, institutions of higher learning in South 
Africa should offer a curriculum that is relevant to twenty-first century skills. The South African government is providing internet connectivity to rural communities to overcome the problem of the digital divide.

The difficulties brought about by the digital divide remain a thorny issue in online learning during the 4IR. A large portion of the budget in developing countries is spent on quality education, and the problems are gradually solved as barriers in online learning fall away. The dialogue in online learning motivates students to learn and succeed in their studies. In such a context, students speak freely and express diverse views that promote social presences in learning. The students develop and promote friendships during the course of online learning. Institutions of higher learning have a duty to generate ideas and solve societal problems. Students should be supported and trained for future jobs. The department should promote sound graduateness in higher education. Successful student support will ensure quality of learning through teaching in the department. The students and lecturers should be reskilled to use new technologies. The institution should use new technologies to understand students better during the 4IR.

\section{Conclusion}

According to the literature review, one of the principal tasks of every university is to educate the youth. In the era of the 4IR, it is important to implement appropriate programmes that will respond to the needs of society. To achieve this, institutions of higher learning need to implement appropriate learning programmes and offer better learning experiences to the students. Educational services have to be improved radically to respond to the economy in the global society.

\section{References}

Agrawal, A., J. Gans, and A. Goldfarb. 2018. Prediction Machines: The Simple Economics of Artificial Intelligence. Harvard Business Review Press.

Brynjolfsson, E., and A. McAfee. 2014. The Second Machine Age: Work, Progress and Prosperity in a Time of Brilliant Technologies. New York: WW Norton.

Castells, M. 2001. The Internet Galaxy. Reflections on the Internet, Business, and Society. Oxford: Oxford University Press.

Gilson, L. L., and C. B. Goldberg. 2015. "Editors' Comment: So, What is a Conceptual Paper?" Group and Organisation Management 40 (2): 127-130.

Harari, Y. N. 2018. 21 Lessons for the 21st century. London: Jonathan Cape. 
Lorenz, M., M. Rubmann, R. Strack, K. L. Lueth, and M. Bolle. 2015. Man and Machine in Industry 4.0: How will Technology Transform the Industrial Work Force through 2025. Boston Consulting Group.

Marwala, T. 2009. Computational Intelligence for Missing Data Implication: Estimation, and Management : Knowledge Optimization Techniques. Pennsylvania: IGI Global. https://doi.org/10.4018/978-1-60566-336-4.

Marwala, T., and E. Hurwitz. 2017. Artificial Intelligence and Economic Theory: Skynet in the Market. New York: Springer. https://doi.org/10.1007/978-3-319-66104-9.

McAfee, A., A. Goldbloom, E. Brynjolfsson, and J. Howard. 2014. “Artificial Intelligence Meets the C-Suite." Mckensey Quarterly 3: 66-75.

Mdluli, S., and O. Makhupe. 2017. Defining Leadership Competencies needed for the Fourth Industrial Revolution: Leadership Competencies 4.0. Africa Expansion Project 2017. Bank Seta.

Moche, G. 2020. “ODL in 4IR Context.” Seminar on Open Distance Learning in the 4IR: Achievement, Challenges and Best Practices. Accessed 20 March 2021. www.Unisa.ac.za/sites/corporate/default/colleges/Education/News-\&events/Articles/ODL-in-4IR-context.

Moloi, T., and T. Marwala. 2020. "Introduction to Artificial Intelligence in Economics and Finance Theories." In Artificial Intelligence in Economics and Finance Theories, 1-12. Cham: Springer. https://doi.org/10.1007/978-3-030-42962-11.

Mtsweni, J., and H. Abdulla. 2014. "The Role of Etutors in Promoting Elearning Using Web 2.0 Technologies.” Paper presented at the African Cyber Citizenship Conference, Port Elizabeth, South Africa.

Norries, P. 2001. Digital Divide: Civic Engagement, Information Poverty and the Internet World-Wide. https://doi.org/10.1108/146366903322008287.

Philbeck, T., and N. Davis. (2018). The Fourth Industrial Revolution. Journal of International Affairs 72 (1): 17-22.

Ramaphosa, C. 2018. Sona 2018. Accessed 23 March 2021. https://www.thesouthafrican.com.

Ravhudzulo, L. 2019. “4IR Deepening in Equalities in South Africa.” Unisa. https://www.unisa.ac.za/sites/corporate/default/news-s-Media/Articles/4IR-deepeninginequalities-in-South Africa.

Schwab, K. M. 2016a. The Fourth Industrial Revolution. Geneva: World Economic Forum.

Schwab, K. M. 2016b. The Fourth Industrial Revolution: What it Means, How to Respond. World Economic Forum Agenda. http://www.Weforum.org/agenda/2016/01/the-fourthIndustrial-revolution-what-it-means-and-how-to-respond. 
Segoe, B. 2017. "Tutor Support in an Open Distance Learning Environment for Upgrading Teachers.” Journal of Human Ecology 48 (1): 161-169. https://doi.org/10.1080/09709274.2014.11906785.

Simpson, O. 2002. Supporting Students in Online Open and Distance Learning. 2nd ed. London: Kogan Page.

Stewart, I., D. De, and A. Cole. 2015. Technology and People: The Great Job-Creating Machine. London: Deloitte.

Tait, A. 2003. "Reflections on Student Support in Open and Distance Learning." International Review of Research in Open and Distributed Learning 4 (1): 1-9. https://doi.org/10.19173/irrodl.v4i1.134.

The Future of Jobs. 2016. Employment, Skills and Workforce Strategy for the Fourth Industrial Revolution. Geneva: World Economic Forum.

The Future of Jobs Report. 2018. Centre for the New Economy and Society. Geneva: World Economic Forum.

Thorpe, M. 2002. "Rethinking Learner Support. The Challenge of Collaborative Online Learning." Open Learning 7 (2): 105-119. https://doi.org/10.1080/02680510220146887a.

Van Dijk, J. A. G. M. 2006. "Digital Divide Research, Achievements and Shortcomings." Poetics 34: 221-35.

World Economic Forum. 2015. Deep Shift: Technology Tipping Points and Societal Impact. Global Agenda Council on the Future of Software and Society, Survey Report. Geneva: World Economic Forum.

Xing, B., and T. Marwala. 2017. "Implications of the Fourth Industrial Age for Higher Education." Thinker 73. https://doi.org/10.25073/0866-773X/87. 